Research, part of a Special Feature on Why does hunting in tropical regions matter?

\title{
Indicators for wild animal offtake: methods and case study for African mammals and birds
}

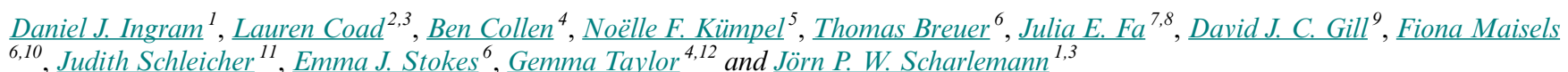

\begin{abstract}
Unsustainable exploitation of wild animals is one of the greatest threats to biodiversity and to millions of people depending on wild meat for food and income. The international conservation and development community has committed to implementing plans for sustainable use of natural resources and has requested development of monitoring systems of bushmeat offtake and trade. Although offtake monitoring systems and indicators for marine species are more developed, information on harvesting terrestrial species is limited. Building on approaches developed to monitor exploitation of fisheries and population trends, we have proposed two novel indicators for harvested terrestrial species: the mean body mass indicator (MBMI) assessing whether hunters are relying increasingly on smaller species over time, as a measure of defaunation, by tracking body mass composition of harvested species within samples across various sites and dates; and the offtake pressure indicator (OPI) as a measure of harvesting pressure on groups of wild animals within a region by combining multiple time series of the number of harvested individuals across species. We applied these two indicators to recently compiled data for West and Central African mammals and birds. Our exploratory analyses show that the MBMI of harvested mammals decreased but that of birds rose between 1966/1975 and 2010. For both mammals and birds the OPI increased substantially during the observed time period. Given our results, time-series data and information collated from multiple sources are useful to investigate trends in body mass of hunted species and offtake volumes. In the absence of comprehensive monitoring systems, we suggest that the two indicators developed in our study are adequate proxies of wildlife offtake, which together with additional data can inform conservation policies and actions at regional and global scales.
\end{abstract}

Key Words: Africa; bushmeat; exploitation; harvest; indicator

\section{INTRODUCTION}

Unsustainable exploitation is one of the greatest threats to terrestrial (Schipper et al. 2008) and marine (Costello et al. 2010) wild animals. Simultaneously, exploitation of wild animals for food, referred to as "wild meat" or "bushmeat," as it is known in Africa (Milner-Gulland et al. 2003), is a major source of animal protein, vitamins, and some minerals for more than a billion of the world's poorest people (Brashares et al. 2014). Because of these contrasting issues, world leaders through the Convention on Biological Diversity (CBD) have committed to taking "steps to achieve or have implemented plans for sustainable production and consumption and have kept the impacts of use of natural resources well within safe ecological limits" (Aichi target 4, CBD 2010). Since 2008, the CBD has required parties to comply with recommendations, resolutions and decisions related to bushmeat issues, and the 11th Conference of the Parties of the CBD explicitly called for the development of "appropriate monitoring systems of bushmeat harvest and trade" (Decision XI/25, CBD 2012). However, limited progress has been made toward developing a comprehensive monitoring system of wild animal offtake, especially for terrestrial species.

An effective monitoring system requires indicators that represent and explain the condition of a monitored variable over time (Jones et al. 2011), usually comprising drivers, pressures, states, and responses for multiple species and geographic scales (Sparks et al. 2011). Although a number of biodiversity indicators have been developed, especially to assess trends in the "state" of habitats, e.g., natural habitat extent (Tittensor et al. 2014), and vertebrate species, e.g., the Living Planet Index, or LPI (Loh et al. 2005), few indicators exist that can inform on key aspects of pressures, responses, and benefits (Balmford et al. 2005, Mace and Baillie 2007, Walpole et al. 2009, Tittensor et al. 2014). Indicators of pressures on wild animals, e.g., harvest levels or offtake, or of the benefits derived from the use of wild animals, e.g., consumption rates, are relatively well developed for marine species, but poorly advanced for terrestrial species.

Knowledge of the spatial and temporal patterns of marine fish stock exploitation has progressed over past decades because of the wealth of data available (Pauly 2007, FAO Statistics Division 2015) from globally available fish stock assessments (MilnerGulland and Akçakaya 2001, Worm et al. 2009). Estimates of the absolute biomass of fish stocks exploited by fisheries are widely considered as the gold standard for fisheries indicators (e.g., Kleisner et al. 2013). For example, Pauly (2007) produced an indicator for the state of marine fisheries based on the plethora of catch data, classifying fisheries from developing to collapsed. The Large Fish Indicator (LFI), another widely used indicator, captures trends in the biomass contribution to the catch of larger individuals or species, which is a response to exploitation, i.e., curtailment of size structure (e.g., Greenstreet et al. 2011, Shephard et al. 2011). However, these indicators based on landing records likely underestimate exploitation because not all harvest is reported, e.g., bycatch and wastage. These two types of

${ }^{1}$ School of Life Sciences, University of Sussex, ${ }^{2}$ Environmental Change Institute, University of Oxford, ${ }^{3}$ United Nations Environment Programme World Conservation Monitoring Centre, ${ }^{4}$ Centre for Biodiversity \& Environment Research, University College London, ${ }^{5}$ Conservation Programmes, Zoological Society of London, ${ }^{6}$ Global Conservation Program, Wildlife Conservation Society, ${ }^{7}$ Division of Biology and Conservation Ecology, School of Science and the Environment, Manchester Metropolitan University, ${ }^{8}$ Center for International Forestry Research, ${ }^{9}$ Fauna \& Flora International, ${ }^{10}$ African Forest Ecology Group, School of Natural Sciences, University of Stirling, ${ }^{11}$ Department of Geography, University of Cambridge, ${ }^{12}$ Institute of Zoology, Zoological Society of London 
indicators, the former utilizing the number of fish caught at a site and the latter the body mass of fish caught to assess changes in stocks over time, provide insights into pressure on and the benefit of fisheries. The same approaches can be applied to terrestrial species.

For terrestrial species, the development of exploitation indicators has largely been hampered by the lack of long-term monitoring data across multiple scales (Weinbaum et al. 2013). Recently, however, Tierney et al. (2014), using time series of vertebrate abundance from the LPI, produced two indicators for wild commodities: the Utilized Species Index (USI) and Harvest Index (HI). The USI uses population data categorized at the species level as "utilized" by humans according to multiple sources including the International Union for Conservation of Nature (IUCN) Red List (IUCN 2009) and the Convention on International Trade in Endangered Species of Wild Fauna and Flora (CITES) Trade Database (CITES 2009). The HI tracks the sustainability of offtake by combining harvest and population data. Both USI and HI are based on population trends, rather than on direct measures of trends in exploitation pressure. Furthermore, both indicators may actually provide conservative estimates of exploitation pressure because not all populations of a species categorized as "utilized" are necessarily impacted by exploitation. Other indicators of wild meat exploitation have collated data from market surveys or on consumption (e.g., Crookes et al. 2005, Brashares et al. 2011, Fa et al. 2015), thereby capturing offtake over larger areas, rather than using more spatially explicit offtake data. Other studies have measured wildlife offtake at the village or trap level, providing information on actual numbers of individuals hunted at known sites (e.g., Noss 1999), often restricted to individual villages (e.g., Van Vliet and Nasi 2008, Kümpel et al. 2010). Currently, these data have not been used to inform indicators of regional or global trends, though offtake studies from individual villages are becoming more readily available, and at a small number of sites, analyses of data over time have been possible (Gill et al. 2012, Coad et al. 2013).

We apply approaches developed for monitoring fisheries offtake and population trends to develop indicators of terrestrial wild meat exploitation. First, we outline two indicators. The first, based on "snapshot data," focuses on investigating trends in the mean body mass of species hunted, analogous to the LFI, and a second investigates trends in offtake by combining time-series data collected at individual sites. Finally, using recently compiled data on wild meat for West and Central Africa (Taylor et al. 2015), supplemented with additional African data from the literature, we conduct exploratory analyses to demonstrate the utility of these data and indicators.

\section{METHODS}

We use the term "offtake" to describe the number of individuals removed from the environment through hunting or harvesting by humans. Although data on wild animal offtake, consumption, and trade at markets are available, we restrict our analyses to offtake data because these provide information on actual numbers of individuals harvested at a known site, whereas consumption and market data provide less spatially explicit information because knowledge of the likely harvest site is lost along the commodity chain (Cowlishaw et al. 2005).
To investigate trends in offtake over time and space, data need to be collated from a variety of sources, often gathered for different purposes. As no standard protocol exists for offtake studies, such compilation includes studies that differ in their taxonomic, geographic, seasonal, and temporal coverage and may also vary in other aspects such as ethnic group, hunting technique, targeted species, taboo species, hunting area, hunting effort, alternative livelihoods, researcher effort, and timing and duration of data collection. Although in practice researchers may concentrate on certain areas and taxa, based on their interests, conservation priorities, and socio-political conditions, or may focus on areas of particularly high harvest, we assume that there is no systematic bias in sampling effort or sites that could affect our analyses.

Data on offtake were collated from a variety of "sources," where source is a published paper, report from a nongovernmental organization, or Ph.D. dissertation or master's thesis. Each source contains one or more "samples"; each sample is a record of the overall wild meat offtake collected at a specific time and site using a specific sampling method. For example, a source providing offtake data for two sites surveyed in both February and October, would be structured as a single source containing four samples, one for each month and site. We assigned a unique identifier (ID) to each sample, unless the sample was part of a time series. We only included data on harvested individuals that could be identified taxonomically to at least class. We separated data into two categories based on the duration over which they were collected, as follows:

1. Snapshot data: Snapshot data refer to samples collected at one site over a continuous period of time within 18 months (Coad et al. 2013). An example of snapshot data is an offtake survey conducted between January and July 2010 in Putu Town, Liberia (Greengrass 2011). These samples may not have recorded offtake throughout an entire year and so may not capture seasonal differences. Wild animal offtake in Africa is often seasonally dependent, affected by climatic conditions, availability of species, and socioeconomic factors such as other financial opportunities for hunters (Allebone-Webb et al. 2011).

2. Time-series data: Time-series data refer to continuous or repeated sampling over multiple years using the same method at the same site and time of year. An example of a time-series data set is the number of putty-nosed monkeys (Cercopithecus nictitans) hunted each year between 1998 and 2008 in northern Republic of Congo (Riddell 2010; Wildlife Conservation Society Noubale-Ndoki Project 1998-2007, unpublished data).

We outline two offtake indicators, one based on snapshot data, i.e., the mean body mass indicator (MBMI), to investigate trends in body mass of offtake as a proxy for species composition, and another, i.e., the offtake pressure indicator (OPI), based on timeseries data, to examine trends in offtake over time across multiple sites.

\section{Two offtake indicators}

Mean body mass indicator

We assessed whether all snapshot data, collected across different sites and times, could be used to develop an indicator of changes 
over time in the composition of hunted species. We proposed using mean body mass within each sample as a proxy of species composition, where a drop from larger to smaller species may indicate a process of defaunation of a habitat (Dirzo et al. 2014). This is analogous to the LFI, which captures changes over time in the contribution of biomass from large fish to the catch (Greenstreet et al. 2011, Shephard et al. 2011). We expected this indicator to decrease if the proportion of small-bodied species increased within the catch over time, either because large-bodied species were extirpated or more smaller-bodied species were being harvested.

An MBMI was calculated by fitting a trend line to the arithmetic mean body mass of the total offtake for each sample for every year, weighted by the number of species harvested. Each sample was weighted by the number of species within the sample, assuming that the number of species is a proxy for sampling effort and to down-weight studies with single or few species. However, differences among studies in the number of species reported may also be caused by other factors such as differences in habitat, site, or harvesting pressure. We attempted to account for this heterogeneity by including ID and country as random factors, and weighting by the number of species, in our statistical analyses.

Body mass data for mammals were collated from Jones et al. (2009) and Kingdon (1997) and for birds from Dunning (2008). For those individuals that were not identified to the species level, we assigned the mean body mass of related taxa found in Africa to the most resolved level taxonomically. To investigate whether year, country, and ID explained any of the variation in mean body mass among samples, we used a linear mixed effects modeling framework, with model selection based on Akaike information criterion (AIC) values (Zuur et al. 2009). We specified year as a fixed effect and tested for nonlinear relationships by including up to third-order polynomial terms. To account for autocorrelation within the data, we compared random factor structures including ID and the country where each sample was collected as random effects. As our data sets are limited to a small number of countries ( 8 countries) with few observations each ( $\leq 8$ studies per country), we fitted country as a random effect (Clark and Linzer 2015). However, as more data become available, fixed effects and interactions among country and year should be explored. All analyses were conducted in the $\mathrm{R}$ statistical computing software, version 3.0.1 (R Core Team 2013), with linear mixed effects models fitted in the lme4 package, version 1.1-7 (Bates et al. 2014).

\section{Offtake pressure indicator}

The offtake pressure exerted on terrestrial species can be represented by the overall trend in number of individuals harvested of each species across sites and years. Time series of multiple species harvested can be aggregated and indexed to calculate an overall trend in the number of individuals harvested. We hypothesize this indicator to increase with increasing number of individuals harvested reflecting an increase in overall hunting pressure, although individual species may decrease.

To quantify trends in offtake pressure, we developed an OPI that combines multiple time series of harvested species. The OPI uses the same method as developed for the LPI (equations 1 to 4 in Collen et al. 2009) to aggregate time series across species and sites using the chain method. The chain method calculates the logarithm of the ratio of the number of individuals harvested, i.e., offtake, for successive years. The mean value of the logarithm of the ratio was calculated for species that had more than 1 time series. For any year within a species-specific time series in which the offtake was 0 , the mean offtake across years was calculated and $1 \%$ of that mean added to each 0 before calculating the index. Missing data points were imputed using log-linear interpolation. Once species-specific means were calculated for each year, the overall mean logarithm of the ratio of the offtake was calculated, weighting each species equally. The index was set to 1 in the first year for which data were available. We calculated $95 \%$ confidence intervals (CIs) for each annual index value using the LPI bootstrap resampling technique (Collen et al. 2009) with 1000 iterations.

Trends in offtake pressure may have occurred before the earliest data were collected, and the "starting point" of hunting, or hunting at high pressure, will likely differ among sites. Therefore, OPI trends need to be interpreted carefully.

The OPI is limited because time-series data are nonindependent of each other, i.e., there are time series for several species for each source and site. Like the LPI, averaging across species-specific time series obscures trends for individual species. For example, in Makao-Linganga (1998-2008) the offtake of 12 species increased, whereas 4 decreased and 14 remained stable. The chain method implemented to produce the OPI is limited because these data were not initially collected through a specifically designed initiative that ensures continuity of data collection. Loh et al. (2005) discuss a few differences between the chain method and least-squares linear modeling results for the LPI and suggest that the least-squares approach would allow the use of full data sets without having to interpolate missing values. More time-series data sets would allow the least-squares approach to be employed more robustly and other nonlinear responses, e.g., using generalized additive models, to be explored.

\section{Data for exploratory analyses}

We extracted all offtake data for mammals and birds from the West and Central African bushmeat database (Taylor et al. 2015). As Taylor et al. (2015) only collated sources investigating all species hunted at each site, we supplemented these data with sources that studied individual species or partial or full communities. We searched for additional data sources from the ISI Web of Science (Thomson Reuters 2014), the Imperial College Conservation Science thesis archive (http://www.iccs. org.uk/publications/thesis-archive-general/), and reference lists. If sources did not contain all information required, we contacted the authors for raw data. We separated data into snapshot and time-series data as outlined previously.

Time series were generated by compiling data from multiple sources that were sampled at the same site using the same method but in different years. When different sources were sampled during different times of the year, we only included data for matching dates. For example, Coad (2007) collected data from October 2003 to February 2005, whereas Schleicher (2010) collected data at the same sites using the same methods from June to August 2010. We therefore used data from June to August from both sources (Coad et al. 2013) and assigned one ID. Some species were reported to be harvested in only some years of a 
time series, and sources did not always report absence of species. When a species was reported to have been harvested in at least one year, we assumed it was not harvested in all other years when not reported and added zeros to complete the time series for the species.

We calculated both indices for mammals and birds separately to investigate whether offtake trends differed between these groups. With more time series available, the OPI could be disaggregated by taxonomic groups; guilds, e.g. herbivores or carnivores; threatened species; and areas, e.g., protected areas or countries, as well as by using more complex analysis techniques including interactions.

\section{RESULTS}

\section{Data}

We extracted data for 18 sources with 41 samples across 29 sites from the West and Central African bushmeat database (Taylor et al. 2015), and another 11 sources with 18 samples across 14 sites from our searches. In total, we compiled data from 29 sources across 43 sites (Fig. 1) for 59 samples (Sabater Pi 1981, Ichikawa 1983, Colell et al. 1994, Kano and Asato 1994, Amubode 1995, Dethier 1995, Kitanishi 1995, Jeanmart 1998, Muchaal and Ngandjui 1999, Noss 1999, Fimbel et al. 2000, Hart 2000, Fa and García Yuste 2001, Kümpel 2006, Yasouka 2006, Brown 2007 , Carpaneto et al. 2007, Coad 2007, Willcox and Nambu 2007, Abugiche 2008, Rist et al. 2008, Gill 2010, Mbete et al. 2010, Riddell 2010, Schleicher 2010, Greengrass 2011, Linder and Oates 2011, Mockrin et al. 2011; Wildlife Conservation Society Noubale-Ndoki Project 1998-2007, unpublished data).

The majority of data were identified to the species $(90.3 \%)$ or genus $(92.7 \%)$ level. Of these, $99.5 \%$ were identified to at least class and included in our analyses. We collated data for 114 species

Fig. 1. Sites in West and Central Africa at which offtake data were collected and used to calculate the mean body mass indicator (black and white circles) and the offtake pressure indicator (white circles). Numbers correspond to time series: 1, Sendje, Equatorial Guinea; 2, Makao-Linganga, Republic of the Congo; 3, Dibouka, Gabon; and 4, Kouagna, Gabon (Table 1, Fig. 3C). Inset shows the area of Africa where sites are located.

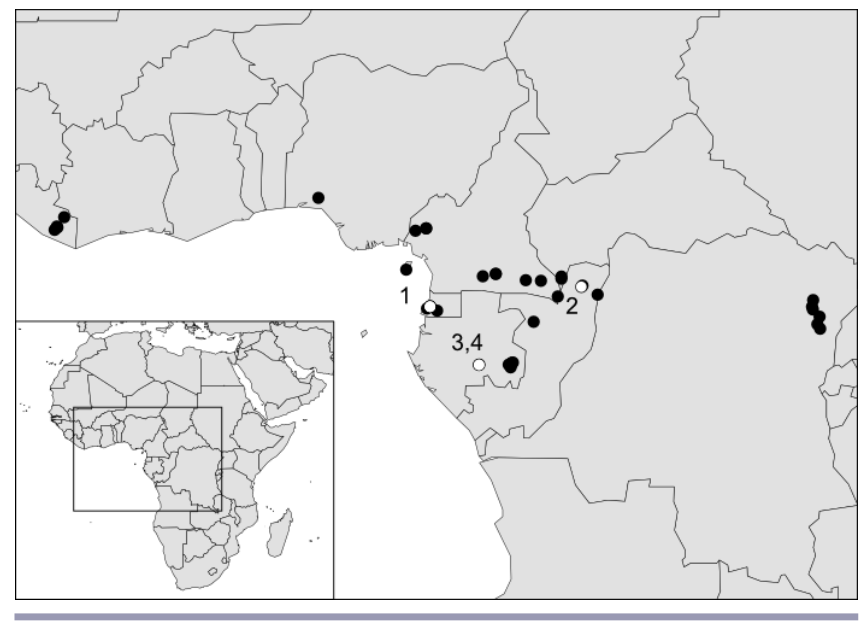

(101 mammals and 13 birds) collected between 1966 and 2010, with the majority of samples gathered between 1985 and 2010. Most data sources (26 sources, or 92.9\%) represented snapshot data.

\section{Mean body mass indicator}

We used data from all 29 sources, encompassing 65,803 harvested individuals, to calculate the MBMI for mammals and birds separately. Data for mammals (59 samples) were available from 1966 to 2010 and for birds (20 samples) from 1975 to 2010.

The MBMI for mammals decreased significantly between 1961 and 2010 (Fig. 2; slope \pm standard error $-0.380 \pm 0.144 \mathrm{~kg} / \mathrm{yr}$; minimum adequate model: mean body mass $=$ year + random effects of ID and country, $\left.\chi_{4,5}^{2}=4.8, p=0.028\right)$. However, for birds it increased significantly between 1975 and $2010(0.055$ $\pm 0.029 \mathrm{~kg} / \mathrm{yr}$; mean body mass $=$ year + random effect of ID, $\chi^{2}$ ${ }_{3,4}=5.5, \mathrm{p}=0.018$ ). For mammals, including the random effect of country resulted in a $\triangle \mathrm{AIC}$ of 10.75 , whereas for birds country effects were nonsignificant and dropped from the model.

Fig. 2. Mean body mass indicator for mammals (gray circles) and birds (black circles) in West and Central Africa. Circles represent offtake samples and are scaled by the number of species harvested within each sample; lines are fitted using linear mixed effects models. Samples are plotted on a logarithmic scale. Note that excluding outliers, 1966 for mammals and 1975 for birds, did not substantially alter the fitted lines.

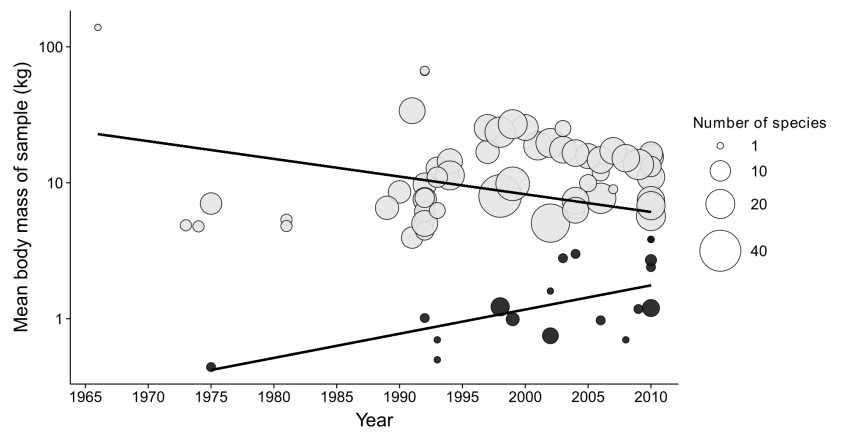

\section{Offtake pressure indicator}

We identified time series from four sites in Central Africa (Table 1) representing 124 species and site-specific time series.

Between 1998 and 2010, the OPI for mammals increased by $231 \%$ to an index value of 3.31 (95\% CI, 1.95-5.82; Fig. 3A). For birds, the OPI increased to 9.73 (95\% CI, 3.78-27.09; Fig. 3B) between 1998 and 2010, an overall increase of $873 \%$.

\section{DISCUSSION}

Indicators tracking anthropogenic pressures exerted on wild animals are valuable for informing conservation policy and action and in tracking efforts toward sustainability and global conservation targets (Mace and Baillie 2007, Weinbaum et al. 2013, Collen and Nicholson 2014). Currently, few indicators are available that track offtake of terrestrial species, especially at broader spatial scales, despite exploitation being one of the major pressures driving wildlife declines worldwide. We have 
Table 1. Details about sites, years sampled, and sample period for four time series used to calculate the offtake pressure indicator. Sample sites are shown in Figure 1.

\begin{tabular}{|c|c|c|c|c|}
\hline $\begin{array}{l}\text { Source No., Site Name, and } \\
\text { Country }\end{array}$ & $\begin{array}{l}\text { Years } \\
\text { (Sample Period) }\end{array}$ & $\begin{array}{l}\text { No. of Species, Mammals/ } \\
\text { Birds }\end{array}$ & $\begin{array}{l}\text { No. of Individuals, } \\
\text { Mammals/Birds }\end{array}$ & Source \\
\hline $\begin{array}{l}\text { 1. Sendje, Equatorial } \\
\text { Guinea }\end{array}$ & $\begin{array}{l}1998,2003,2010 \\
\text { (5 May to 26 June) }\end{array}$ & $30 / 9$ & $1313 / 65$ & $\begin{array}{l}\text { Fa and García Yuste 2001, } \\
\text { Kümpel 2006, Gill } 2010\end{array}$ \\
\hline $\begin{array}{l}\text { 2. Makao-Linganga, } \\
\text { Republic of the Congo }\end{array}$ & $\begin{array}{l}1998-2007,2008 \\
\text { (all year) }\end{array}$ & $26 / 3$ & $12,141 / 38$ & $\begin{array}{l}\text { Riddell 2010; Wildlife } \\
\text { Conservation Society } \\
\text { Noubale-Ndoki Project } \\
\text { 1998-2007, unpublished } \\
\text { data }\end{array}$ \\
\hline 3. Dibouka, Gabon & $\begin{array}{l}\text { 2004, } 2010 \\
\text { (14 June to } 12 \text { August) }\end{array}$ & $24 / 5$ & $327 / 25$ & Coad 2007, Schleicher 2010 \\
\hline 4. Kouagna, Gabon & $\begin{array}{l}\text { 2004, } 2010 \\
\text { (14 June to } 12 \text { August) }\end{array}$ & $24 / 3$ & $342 / 3$ & Coad 2007, Schleicher 2010 \\
\hline
\end{tabular}

Fig. 3. Offtake pressure indicator for mammals (A) and birds (B) in Central Africa and the distribution of time-series data at the four sites listed in Table $1(\mathrm{C})$. The indicator is set to 1 in the first year for which data were available (dotted horizontal line). Shading (A and B) represents $\pm 95 \%$ confidence intervals generated with 1000 bootstrap replicates. Width of bars (C) represents the number of mammal (gray) and bird (black) species sampled at four sites (numbers refer to sample sites shown in Fig. 1 and Table 1).

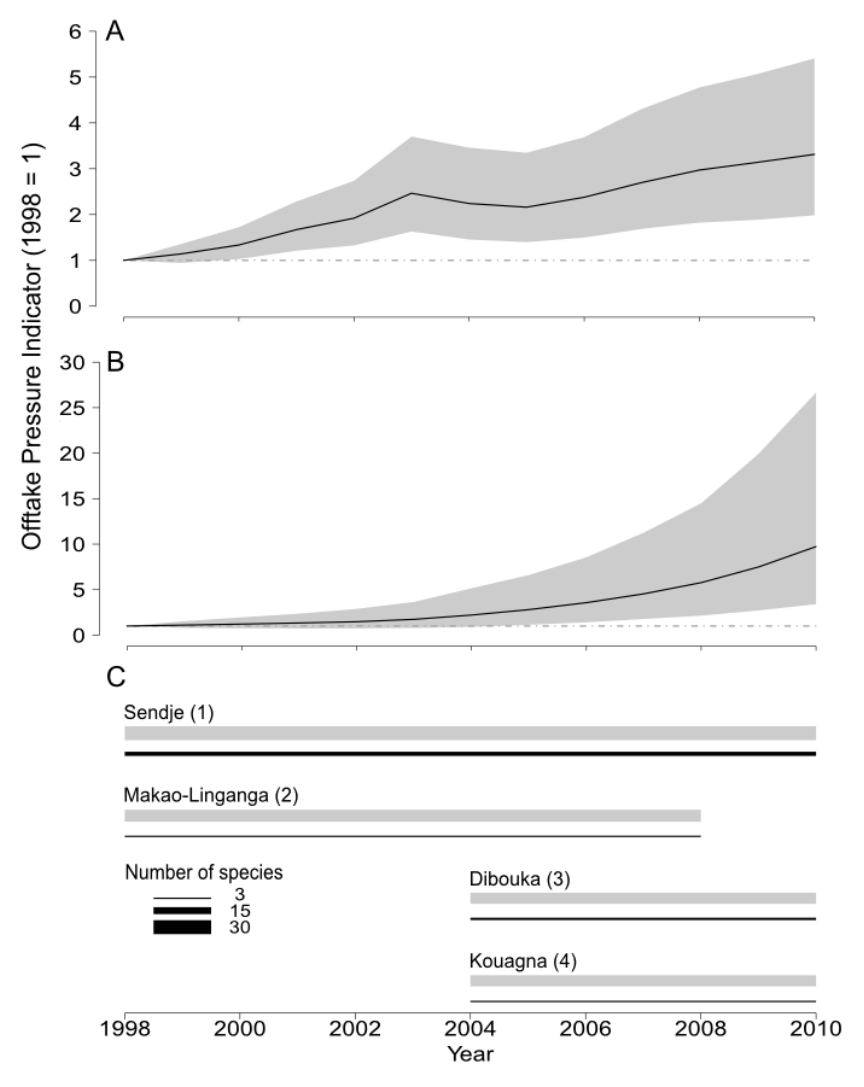

investigated and outlined two different methods to track the offtake of wild terrestrial species using data extracted from the existing literature for West and Central Africa.

\section{Two offtake indicators}

We showed that trends in composition of harvested species and offtake pressure can be observed when approaches used in monitoring fisheries exploitation and population trends are applied to compiled data on wild meat for West and Central Africa. Our indicators provide a means of integrating taxonomically, spatially, and temporally disparate data collated from multiple sources. The two indicators offer insights into different aspects of wildlife exploitation dynamics and are useful in understanding trends in hunted wildlife in Africa. The MBMI is a proxy for temporal changes in the composition of harvested species averaged at each site, whereas the OPI provides a measure of relative change in the number of harvested individuals indexed across multiple sites and species. The currently available data allowed us to produce separate indices for the main two taxonomic groups exploited, i.e., mammals and birds. As more data become available, indicators at finer taxonomic; ecological, e.g., genera, feeding guilds, or functional traits; and spatial, e.g., country or ecoregion, resolutions can be produced. Despite the limited data currently available, we provide two methodologies to calculate trends in composition of species harvested and offtake pressure that have potential for guiding conservation policies and actions.

With the data available for our exploratory analyses for West and Central African mammals and birds, we show that the composition of harvested species, as measured by the MBMI, changed and the OPI increased significantly over time. Between 1966 and 2010, the average body mass of harvested mammals declined, whereas that of birds increased between 1975 and 2010, indicating a change in the composition of species harvested, as shown by the MBMI (Fig. 2). The indexed number of individuals harvested of both mammals and birds increased dramatically between 1998 and 2010 (Fig. 3).

One may be tempted to compare MBMI and OPI to conclude that hunting pressure continues to increase for African species, with hunting of smaller mammals being compensated by larger birds. However, such a direct comparison is not valid because the data sets used are only partially overlapping in space and time 
and were used simply to demonstrate the feasibility of applying the two indicator methodologies. Furthermore, MBMI and OPI are calculated differently, with the former employing an arithmetic mean and the latter a geometric mean. We would, therefore, expect the MBMI to change more rapidly compared to the OPI; hence, these two indicators will not directly align. With more time series at multiple sites available, it would be possible to calculate both indicators for the same sites and compare them.

These two indicators offer potentially useful approaches to assess wildlife offtake in the absence of comprehensive monitoring schemes, especially once the limitations as outlined subsequently have been addressed. The increase in average body mass of harvested birds, shown by the MBMI, may reflect a change in the demand for larger birds and their bills, such as the Black-casqued Hornbill (Ceratogymna atrata), in the Sendje time series. The MBMI may indicate that hunting down a size gradient has occurred over time across the region, which has been reported from studies at individual sites (e.g., Gill et al. 2012, Coad et al. 2013). The size of remaining mammalian fauna in the forests today will likely be generally smaller; this has probably had multiple effects on ecosystem function (Abernethy et al. 2013), including changes in forest composition (Beaune et al. 2013, Effiom et al. 2013) and nutrient cycling (Doughty et al. 2013a, $b$, Wolf et al. 2013). Trends in both MBMI and OPI need to be interpreted carefully, especially when data from different types of hunting, e.g. subsistence and trophy, are included, because species and number of individuals hunted are likely determined by different demands.

\section{Limitations and future developments}

In addition to the indicator limitations discussed in the Methods, offtake data collection relies on the willingness and availability of hunters to participate in research; therefore, sources likely sampled a subset of hunters at a site. Moreover, offtake by women and children, or that harvested for subsistence rather than trade, is often overlooked in studies, although this contribution to the harvest could be substantial (see Kümpel 2006). Hunters may also purposefully avoid, or fail to report, harvesting certain species while research is ongoing, because these species are legally protected and law enforcement is strict in their area. This is likely to be the case for gorilla (Gorilla gorilla) and chimpanzee (Pan troglodytes) hunting at Makao (site 2, Fig. 1). Our indicator methodologies attempt to account for heterogeneity among sources. As more studies on wild meat offtake become available, more rigorous statistical analyses can control for some of these factors, although we recognize that it is impossible to account for all of them.

The MBMI uses mean body mass of the sample as a proxy for species composition; however, analogous indicators could be produced based on other traits of species. For example, to assess whether hunters rely increasingly on smaller, faster-reproducing species, indicators could incorporate the ratio of small to large animals, the ratio of $r$-selected to $K$-selected species (Fa et al. 2015), or the trophic level of harvested species (Pauly and Watson 2005). Furthermore, the MBMI is fitting a trend across samples from disparate sites and taxonomic coverage, with some taxa entering and leaving the index as studies focus on particular taxa. With more data included in the MBMI, the effects of dropping in and out should become less of an issue.
The OPI presented is based on 124 species-specific time series from 4 sites that overlapped sufficiently; therefore, interpreting the index should be restricted to species and sites included. Moreover, the baseline against which the index is calculated is important because trends may have occurred before the earliest data collected or started at different times among sites. This was indeed the case in the two Gabonese villages included (Coad et al. 2013).

More data on wild meat harvest are available from consumption and market trade studies. However, these data have not been included because they usually represent a larger and often unquantified area over which wild meat has been harvested. Furthermore, comparing and combining data collected on consumption and trade with offtake data is not without difficulties (Allebone-Webb et al. 2011). Indicators utilizing consumption and market data, separately or in combination, could offer additional insights into the wild meat harvest dynamics.

\section{CONCLUSION}

Our indicator methods suggest that existing heterogeneous data from multiple sources can be used to gain information about aspects of wild meat offtake dynamics. We can use not only timeseries data sets but also the more commonly collected snapshot data. The quality and quantity of data used to produce an indicator affect how representative the indicator is (Collen and Nicholson 2014); therefore, investigating multiple indicators based on the most readily available data over large spatial scales may improve the chances of producing more representative indicators. Furthermore, identifying causal links between changes in pressure on and the state of wild animal populations is often difficult. The wild animal offtake indicators we have showcased have the potential to establish such linkages when combined with indicators of state to potentially estimate sustainable exploitation.

Our analyses are based on data collected over 40 years by many researchers, and even with this amount of effort, the indicators are limited in what they can show, highlighting the likely large investment required to produce robust and sensitive indicators that can inform policy. To gain more detailed insights into wild meat dynamics by applying these novel indicators in the future, existing data on wild meat offtake need to be collated and new data collected, ideally by systematic monitoring schemes (e.g., Système de suivi de la filière "viande de brousse" en Afrique Centrale; Ringuet et al. 2010) enabled by innovative technologies, such as mobile telephone apps. Establishing a monitoring network for wildlife hunting and trade could provide data for future largescale long-term indicator analyses. Existing global data on terrestrial wild meat offtake, consumption, and trade are currently being collated by the OFFTAKE database (http://www.offtake. org). This database encompasses the West and Central African bushmeat database (Taylor et al. 2015) and welcomes additional data. Using these data in predictive modeling, ground-truthed by field studies, will likely help guide conservation decisions. The indicators explored, given more data over space and time, could prove informative for assessments of wildlife exploitation as both a threat to wild animals and a benefit to people at local, national, and global scales. 


\begin{abstract}
Acknowledgments:
We are grateful to all researchers and organizations that contributed to wild meat data collection and provided access to their data; the governments of Cameroon, Central African Republic, Republic of the Congo, Democratic Republic of the Congo, Equatorial Guinea, Gabon, Liberia, and Nigeria for support to individuals and projects collecting data; the Wildlife Conservation Society, Global Conservation Program for management of the Noubale-Ndoki Project data set, in particular Stephen Blake, Michael Riddell, Hannah Thomas, and an anonymous staff member; and Claudia Gray for advice and comments on an earlier draft of the manuscript. We acknowledge support from the School of Life Sciences, University of Sussex for a doctoral training grant for D. J. Ingram; USFWS and USAID-CARPE to the Wildlife Conservation Society for long-term research in the northern Republic of the Congo; and the Rufford Foundation, USFWS, and the United Kingdom's Natural Environment Research Council (NERC) and Economic and Social Research Council (ESRC) to N. F. Kümpel for research in Equatorial Guinea.
\end{abstract}

\section{LITERATURE CITED}

Abernethy, K. A., L. Coad, G. Taylor, M. E. Lee, and F. Maisels. 2013. Extent and ecological consequences of hunting in Central African rainforests in the twenty-first century. Philosophical Transactions of the Royal Society B 368:20130494. http://dx.doi. org/10.1098/rstb.2013.0494

Abugiche, S. A. 2008. Impact of hunting and bushmeat trade on biodiversity loss in Cameroon: a case study of the Banyang-Mbo Wildlife Sanctuary. Dissertation. Brandenburg University of Technology, Cottbus, Germany.

Allebone-Webb, S. M., N. F. Kümpel, J. Rist, G. Cowlishaw, J. M. Rowcliffe, and E. J. Milner-Gulland. 2011. Use of market data to assess bushmeat hunting sustainability in Equatorial Guinea. Conservation Biology 25:597-606. http://dx.doi.org/10.1111/ j.1523-1739.2011.01681.x

Amubode, F. O. 1995. Changes in harvest rate and age-sex composition of wildlife harvest in Omo forest reserve, Nigeria. Nature et Faune 11:22-32.

Balmford, A., P. Crane, A. Dobson, R. E. Green, and G. M. Mace. 2005. The 2010 challenge: data availability, information needs and extraterrestrial insights. Philosophical Transactions of the Royal Society B 360:221-288. http://dx.doi.org/10.1098/rstb.2004.1599

Bates, D., M. Maechler, B. Bolker, and S. Walker. 2014. Ime4: linear mixed-effects models using Eigen and S4. R package version 1.1-7. R Foundation for Statistical Computing, Vienna, Austria. [online] URL: http://CRAN.R-project.org/package=lme4

Beaune, D., B. Fruth, L. Bollache, G. Hohmann, and F. Bretagnolle. 2013. Doom of the elephant-dependent trees in a Congo tropical forest. Forest Ecology and Management 295:109-117. http://dx.doi.org/10.1016/j.foreco.2012.12.041

Brashares, J. S., B. Abrahms, K. J. Fiorella, C. D. Golden, C. E. Hojnowski, R. A. Marsh, D. J. McCauley, T. A. Nuñez, K. Seto, and L. Withey. 2014. Wildlife decline and social conflict. Science 345:376-378. http://dx.doi.org/10.1126/science.1256734

Brashares, J. S., C. D. Golden, K. Z. Weinbaum, C. B. Barrett, and G. V. Okello. 2011. Economic and geographic drivers of wildlife consumption in rural Africa. Proceedings of the National Academy of Sciences of the United States of America 108:13931-13936. http://dx.doi.org/10.1073/pnas.1011526108

Brown, E. 2007. Managing hunting and transportation of wildlife in and around the Okapi Faunal Reserve, Democratic Republic of Congo. Wildlife Conservation Society, New York, New York, USA.

Carpaneto, G. M., A. Fusari, and H. Okongo. 2007. Subsistence hunting and exploitation of mammals in the Haut-Ogooué province, south-eastern Gabon. Journal of Anthropological Sciences 85:183-193.

Clark, T. S., and D. A. Linzer. 2015. Should I use fixed or random effects? Political Science Research and Methods 3:399-408. http:// dx.doi.org/10.1017/psrm.2014.32

Coad, L. 2007. Bushmeat hunting in Gabon: socio-economics and hunter behaviour. Dissertation. University of Cambridge, Cambridge, UK.

Coad, L., J. Schleicher, E. J. Milner-Gulland, T. R. Marthews, M. Starkey, A. Manica, A. Balmford, W. Mbombe, T. R. Diop Bineni, and K. A. Abernethy. 2013. Social and ecological change over a decade in a village hunting system, central Gabon. Conservation Biology 27:270-280. http://dx.doi.org/10.1111/cobi.12012

Colell, M., C. Maté, and J. E. Fa. 1994. Hunting among Moka Bubis in Bioko: dynamics of fauna exploitation at the village level. Biodiversity and Conservation 3:939-950. http://dx.doi.org/10.1007/ $\underline{\mathrm{BF} 00129668}$

Collen, B., J. Loh, S. Whitmee, L. McRae, R. Amin, and J. E. M. Baillie. 2009. Monitoring change in vertebrate abundance: the Living Planet Index. Conservation Biology 23:317-327. http://dx. doi.org/10.1111/j.1523-1739.2008.01117.x

Collen, B., and E. Nicholson. 2014. Taking the measure of change. Science 346:166-167. http://dx.doi.org/10.1126/science. 1255772

Convention on Biological Diversity (CBD). 2010. COP 10 decision X/2: X/2. Strategic plan for biodiversity 2011-2020. CBC, Montréal, Québec, Canada. [online] URL: http://www.cbd.int/ decision/cop/?id=12268

Convention on Biological Diversity (CBD). 2012. COP 11 decision XI/25: XI/25. Sustainable use of biodiversity: bushmeat and sustainable wildlife management. CBC, Montréal, Québec, Canada. [online] URL: https://www.cbd.int/decision/cop/ default.shtml?id=13186

Convention on International Trade in Endangered Species of Wild Fauna and Flora (CITES). 2009. CITES trade database. CITES, Geneva, Switzerland. [online] URL: http://www.cites. org/eng/resources/trade.shtml

Costello, M. J., M. Coll, R. Danovaro, P. Halpin, H. Ojaveer, and P. Miloslavich. 2010. A census of marine biodiversity knowledge, resources, and future challenges. PLoS ONE 5(8):e12110. http:// dx.doi.org/10.1371/journal.pone.0012110 
Cowlishaw, G., S. Mendelson, and J. M. Rowcliffe. 2005. Structure and operation of a bushmeat commodity chain in southwestern Ghana. Conservation Biology 19:139-149.

Crookes, D. J., N. Ankudey, and E. J. Milner-Gulland. 2005. The value of a long-term bushmeat market dataset as an indicator of system dynamics. Environmental Conservation 32:333-339. http:// dx.doi.org/10.1017/S037689290500250X

Dethier, M. 1995. Etude Chasse: Projet ECOFAC - Composante Cameroun. AGRECO, Bruxelles, Belgium.

Dirzo, R., H. S. Young, M. Galetti, G. Ceballos, N. J. B. Isaac, and B. Collen. 2014. Defaunation in the Anthropocene. Science 345:401-406. http://dx.doi.org/10.1126/science.1251817

Doughty, C. E., A. Wolf, and Y. Malhi. 2013a. The impact of large animal extinctions on nutrient fluxes in early river valley civilizations. Ecosphere 4:art148. http://dx.doi.org/10.1890/ ES13-00221.1

Doughty, C. E., A. Wolf, and Y. Malhi. 2013b. The legacy of the Pleistocene megafauna extinctions on nutrient availability in Amazonia. Nature Geoscience 6:761-764. http://dx.doi. org/10.1038/ngeo1895

Dunning, J. B., Jr. 2008. CRC handbook of avian body masses. Second edition. CRC, Boca Raton, Florida, USA.

Effiom, E. O., G. Nuñez-Iturri, H. G. Smith, U. Ottosson, and O. Olsson. 2013. Bushmeat hunting changes regeneration of African rainforests. Proceedings of the Royal Society B 280:20130246. http://dx.doi.org/10.1098/rspb.2013.0246

Fa, J. E., and J. E. Garcia Yuste. 2001. Commercial bushmeat hunting in the Monte Mitra forests, Equatorial Guinea: extent and impact. Animal Biodiversity and Conservation 24:31-52.

Fa, J. E., J. Olivero, M. Á. Farfán, A. L. Márquez, J. Duarte, J. Nackoney, A. Hall, J. Dupain, S. Seymour, P. J. Johnson, D. W. Macdonald, R. Real, and J. M. Vargas. 2015. Correlates of bushmeat in markets and depletion of wildlife. Conservation Biology 29:805-815. http://dx.doi.org/10.1111/cobi.12441

Fimbel, C., B. Curran, and L. Usongo. 2000. Enhancing the sustainability of duiker hunting through community participation and controlled access in the Lobéké region of southeastern Cameroon. Pages 356-374 in J. G. Robinson and E. L. Bennett, editors. Hunting for sustainability in tropical forests. Columbia University Press, New York, New York, USA.

Food and Agriculture Organization of the United Nations (FAO) Statistics Division. 2015. FAOSTAT. FAO, Rome, Italy. [online] URL: http://faostat.fao.org/

Gill, D. 2010. Drivers of change in hunter offtake and hunting strategies in Sendje, Equatorial Guinea. Thesis. Imperial College London, London, UK.

Gill, D. J. C., J. E. Fa, J. M. Rowcliffe, and N. F. Kümpel. 2012. Drivers of change in hunter offtake and hunting strategies in Sendje, Equatorial Guinea. Conservation Biology 26:1052-1060. http://dx.doi.org/10.1111/j.1523-1739.2012.01876.x

Greengrass, E. 2011. Exploring the dynamics of bushmeat hunting and trade in Sapo National Park. Fauna \& Flora International, Cambridge, UK.
Greenstreet, S. P. R., S. I. Rogers, J. C. Rice, G. J. Piet, E. J. Guirey, H. M. Fraser, and R. J. Fryer. 2011. Development of the EcoQO for the North Sea fish community. ICES Journal of Marine Science 68:1-11. http://dx.doi.org/10.1093/icesjms/fsq156

Hart, J. A. 2000. Impact and sustainability of indigenous hunting in the Ituri forest, Congo-Zaire: a comparison of unhunted and hunted duiker populations. Pages 106-153 in J. G. Robinson and E. L. Bennett, editors. Hunting for sustainability in tropical forests. Columbia University Press, New York, New York, USA.

Ichikawa, M. 1983. An examination of the hunting-dependent life of the Mbuti Pygmies, Eastern Zaire. African Study Monographs 4:55-76.

International Union for Conservation of Nature (IUCN). 2009. The IUCN Red List of Threatened Species. Version 2009. IUCN, Cambridge, UK. [online] URL: http://www.iucnredlist.org

Jeanmart, P. 1998. Tentative d'elaboration d'un plan de Gestion de la Chasse Villageoise dans la Reserve de Faune du Dja. Rapport ECOFAC-Cameroun (Conservation et utilisation rationnelle des écosystèmes Forestiers d'Afrique centrale). AGRECO, Bruxelles, Belgium.

Jones, K. E., J. Bielby, M. Cardillo, S. A. Fritz, J. O’Dell, C. D. L. Orme, K. Safi, W. Sechrest, E. H. Boakes, C. Carbone, C. Connolly, M. J. Cutts, J. K. Foster, R. Grenyer, M. Habib, C. A. Plaster, S. A. Price, E. A. Rigby, J. Rist, A. Teacher, O. R. P. Bininda-Emonds, J. L. Gittleman, G. M. Mace, A. Purvis, and W. K. Michener. 2009. PanTHERIA: a species-level database of life history, ecology, and geography of extant and recently extinct mammals. Ecology 90:2648. http://dx.doi.org/10.1890/08-1494.1

Jones, J. P. G., B. Collen, G. Atkinson, P. W. J. Baxter, P. Bubb, J. B. Illian, T. E. Katzner, A. Keane, J. Loh, E. McDonald-Madden, E. Nicholson, H. M. Pereira, H. P. Possingham, A. S. Pullin, A. S. L. Rodrigues, V. Ruiz-Gutierrez, M. Sommerville, and E. J. Milner-Gulland. 2011. The why, what, and how of global biodiversity indicators beyond the 2010 target. Conservation Biology 25:450-457. http://dx.doi.org/10.1111/j.1523-1739.2010.01605. $\underline{\mathrm{x}}$

Kano, T., and R. Asato. 1994. Hunting pressure on chimpanzees and gorillas in the Motaba river area, northeastern Congo. African Study Monographs 15:143-162.

Kingdon, J. 1997. The Kingdon field guide to African mammals. Academic, San Diego, California, USA.

Kitanishi, K. 1995. Seasonal changes in the subsistence activities and food intake of the Aka hunter-gatherers in northeastern Congo. African Study Monographs 16:73-118.

Kleisner, K., D. Zeller, R. Froese, and D. Pauly. 2013. Using global catch data for inferences on the world's marine fisheries. Fish and Fisheries 14:293-311. http://dx.doi.org/10.1111/j.1467-2979.2012.00469. $\underline{x}$

Kümpel, N. F. 2006. Incentives for sustainable hunting of bushmeat in Río Muni, Equatorial Guinea. Dissertation. Imperial College London, London, UK.

Kümpel, N. F., E. J. Milner-Gulland, G. Cowlishaw, and J. M. Rowcliffe. 2010. Assessing sustainability at multiple scales in a rotational bushmeat hunting system. Conservation Biology 


\section{4:861-871. http://dx.doi.org/10.1111/j.1523-1739.2010.01505.x}

Linder, J. M., and J. F. Oates. 2011. Differential impact of bushmeat hunting on monkey species and implications for primate conservation in Korup National Park, Cameroon. Biological Conservation 144:738-745. http://dx.doi.org/10.1016/j. biocon.2010.10.023

Loh, J., R. E. Green, T. Ricketts, J. Lamoreux, M. Jenkins, V. Kapos, and J. Randers. 2005. The Living Planet Index: using species population time series to track trends in biodiversity. Philosophical Transactions of the Royal Society B 360:289-295. http://dx.doi.org/10.1098/rstb.2004.1584

Mace, G. M., and J. E. M. Baillie. 2007. The 2010 biodiversity indicators: challenges for science and policy. Conservation Biology 21:1406-1413. http://dx.doi.org/10.1111/j.1523-1739.2007.00830. $\underline{\mathrm{x}}$

Mbete, P., C. Ngokaka, F. Akouango, N. Bonazebi, and J. Vouidibio. 2010. Evaluation des quantités de gibiers prélevées autour du Parc National d' Odzala-Kokoua et leurs impacts sur la dégradation de la biodiversité. Journal of Animal \& Plant Sciences 8:1061-1069.

Milner-Gulland, E. J., and H. R. Akçakaya. 2001. Sustainability indices for exploited populations. Trends in Ecology \& Evolution 16:686-692. http://dx.doi.org/10.1016/s0169-5347(01)02278-9

Milner-Gulland, E. J., E. L. Bennett, and the SCB 2002 Annual Meeting Wild Meat Group. 2003. Wild meat: the bigger picture. Trends in Ecology \& Evolution 18:351-357. http://dx.doi. org/10.1016/s0169-5347(03)00123-X

Mockrin, M. H., R. F. Rockwell, K. H. Redford, and N. S. Keuler. 2011. Effects of landscape features on the distribution and sustainability of ungulate hunting in northern Congo. Conservation Biology 25:514-525. http://dx.doi.org/10.1111/ j.1523-1739.2011.01660.x

Muchaal, P. K., and G. Ngandjui. 1999. Impact of village hunting on wildlife populations in the Western Dja Reserve, Cameroon. Conservation Biology 13:385-396. http://dx.doi.org/10.1046/ j.1523-1739.1999.013002385.x

Noss, A. J. 1999. Censusing rainforest game species with communal net hunts. African Journal of Ecology 37:1-11. http:// dx.doi.org/10.1046/j.1365-2028.1999.00154.x

Pauly, D. 2007. The Sea Around Us Project: documenting and communicating global fisheries impacts on marine ecosystems. AMBIO: A Journal of the Human Environment 36:290-295. http:// dx.doi.org/10.1579/0044-7447(2007)36[290:TSAUPD]2.0.CO;2

Pauly, D., and R. Watson. 2005. Background and interpretation of the 'Marine Trophic Index' as a measure of biodiversity. Philosophical Transactions of the Royal Society B 360:415-423. http://dx.doi.org/10.1098/rstb.2004.1597

R Core Team. 2013. R: a language and environment for statistical computing. R Foundation for Statistical Computing, Vienna, Austria. [online] URL: http://www.R-project.org/

Riddell, M. A. 2010. Hunting and rural livelihoods in northern Republic of Congo: local outcomes of integrated conservation and development. Dissertation. University of Oxford, Oxford, UK.
Ringuet, S., N. Van Vliet, R. Melisch, and G. Ngandjui. 2010. Developpement d'un système de suivi de la viande de brousse en Afrique Centrale (SYVBAC). TRAFFIC International, Cambridge, UK.

Rist, J., M. Rowcliffe, G. Cowlishaw, and E. J. Milner-Gulland. 2008. Evaluating measures of hunting effort in a bushmeat system. Biological Conservation 141:2086-2099. http://dx.doi. org/10.1016/j.biocon.2008.06.005

Sabater Pi, J. 1981. Exploitation of gorillas Gorilla gorilla gorilla Savage \& Wyman 1847 in Rio Muni, Republic of Equatorial Guinea, West Africa. Biological Conservation 19:131-140. http:// dx.doi.org/10.1016/0006-3207(81)90048-3

Schipper, J., J. S. Chanson, F. Chiozza, N. A. Cox, M. Hoffmann, V. Katariya, J. Lamoreux, A. S. L. Rodrigues, S. N. Stuart, H. J. Temple, J. Baillie, L. Boitani, T. E. Lacher Jr., R. A. Mittermeier, A. T. Smith, D. Absolon, J. M. Aguiar, G. Amori, N. Bakkour, R. Baldi, R. J. Berridge, J. Bielby, P. A. Black, J. J. Blanc, T. M. Brooks, J. A. Burton, T. M. Butynski, G. Catullo, R. Chapman, Z. Cokeliss, B. Collen, J. Conroy, J. G. Cooke, G. A. B. da Fonseca, A. E. Derocher, H. T. Dublin, J. W. Duckworth, L. Emmons, R. H. Emslie, M. Festa-Bianchet, M. Foster, S. Foster, D. L. Garshelis, C. Gates, M. Gimenez-Dixon, S. Gonzalez, J. F. Gonzalez-Maya, T. C. Good, G. Hammerson, P. S. Hammond, D. Happold, M. Happold, J. Hare, R. B. Harris, C. E. Hawkins, M. Haywood, L. R. Heaney, S. Hedges, K. M. Helgen, C. HiltonTaylor, S. A. Hussain, N. Ishii, T. A. Jefferson, R. K. B. Jenkins, C. H. Johnston, M. Keith, J. Kingdon, D. H. Knox, K. M. Kovacs, P. Langhammer, K. Leus, R. Lewison, G. Lichtenstein, L. F. Lowry, Z. Macavoy, G. M. Mace, D. P. Mallon, M. Masi, M. W. McKnight, R. A. Medellín, P. Medici, G. Mills, P. D. Moehlman, S. Molur, A. Mora, K. Nowell, J. F. Oates, W. Olech, W. R. L. Oliver, M. Oprea, B. D. Patterson, W. F. Perrin, B. A. Polidoro, C. Pollock, A. Powel, Y. Protas, P. Racey, J. Ragle, P. Ramani, G. Rathbun, R. R. Reeves, S. B. Reilly, J. E. Reynolds III, C. Rondinini, R. G. Rosell-Ambal, M. Rulli, A. B. Rylands, S. Savini, C. J. Schank, W. Sechrest, C. Self-Sullivan, A. Shoemaker, C. Sillero-Zubiri, N. De Silva, D. E. Smith, C. Srinivasulu, P. J. Stephenson, N. van Strien, B. K. Talukdar, B. L. Taylor, R. Timmins, D. G. Tirira, M. F. Tognelli, K. Tsytsulina, L. M. Veiga, J.-C. Vié, E. A. Williamson, S. A. Wyatt, Y. Xie, and B. E. Young. 2008. The status of the world's land and marine mammals: diversity, threat, and knowledge. Science 322:225-230. http://dx. doi.org/10.1126/science. 1165115

Schleicher, J. 2010. The sustainability of bushmeat hunting in two villages in central Gabon. Thesis. University of Oxford, Oxford, UK.

Shephard, S., D. G. Reid, and S. P. R. Greenstreet. 2011. Interpreting the large fish indicator for the Celtic Sea. ICES Journal of Marine Science 68:1963-1972. http://dx.doi. org/10.1093/icesjms/fsr114

Sparks, T. H., S. H. M. Butchart, A. Balmford, L. Bennun, D. Stanwell-Smith, M. Walpole, N. R. Bates, B. Bomhard, G. M. Buchanan, A. M. Chenery, B. Collen, J. Csirke, R. J. Diaz, N. K. Dulvy, C. Fitzgerald, V. Kapos, P. Mayaux, M. Tierney, M. Waycott, L. Wood, and R. E. Green. 2011. Linked indicator sets for addressing biodiversity loss. Oryx 45:411-419. http://dx.doi. org/10.1017/S003060531100024X 
Taylor, G., J. P. W. Scharlemann, M. Rowcliffe, N. Kümpel, M. B. J. Harfoot, J. E. Fa, R. Melisch, E. J. Milner-Gulland, S. Bhagwat, K. A. Abernethy, A. S. Ajonina, L. Albrechtsen, S. AlleboneWebb, E. Brown, D. Brugiere, C. Clark, M. Colell, G. Cowlishaw, D. Crookes, E. De Merode, J. Dupain, T. East, D. Edderai, P. Elkan, D. Gill, E. Greengrass, C. Hodgkinson, O. Ilambu, P. Jeanmart, J. Juste, J. M. Linder, D. W. Macdonald, A. J. Noss, P. U. Okorie, V. J. J. Okouyi, S. Pailler, J. R. Poulsen, M. Riddell, J. Schleicher, B. Schulte-Herbrüggen, M. Starkey, N. van Vliet, C. Whitham, A. S. Willcox, D. S. Wilkie, J. H. Wright, and L. M. Coad. 2015. Synthesising bushmeat research effort in West and Central Africa: a new regional database. Biological Conservation 181:199-205. http://dx.doi.org/10.1016/j.biocon.2014.11.001

Thomson Reuters. 2014. ISI Web of Science. Thomson Reuters, New York, New York, USA.

Tierney, M., R. Almond, D. Stanwell-Smith, L. McRae, C. Zöckler, B. Collen, M. Walpole, J. Hutton, and S. de Bie. 2014. Use it or lose it: measuring trends in wild species subject to substantial use. Oryx 48:420-429. http://dx.doi.org/10.1017/ $\underline{\mathrm{S} 0030605313000653}$

Tittensor, D. P., M. Walpole, S. L. L. Hill, D. G. Boyce, G. L. Britten, N. D. Burgess, S. H. M. Butchart, P. W. Leadley, E. C. Regan, R. Alkemade, R. Baumung, C. Bellard, L. Bouwman, N. J. Bowles-Newark, A. M. Chenery, W. W. L. Cheung, V. Christensen, H. D. Cooper, A. R. Crowther, M. J. R. Dixon, A. Galli, V. Gaveau, R. D. Gregory, N. L. Gutierrez, T. L. Hirsch, R. Höft, S. R. Januchowski-Hartley, M. Karmann, C. B. Krug, F. J. Leverington, J. Loh, R. K. Lojenga, K. Malsch, A. Marques, D. H. W. Morgan, P. J. Mumby, T. Newbold, K. Noonan-Mooney, S. N. Pagad, B. C. Parks, H. M. Pereira, T. Robertson, C. Rondinini, L. Santini, J. P. W. Scharlemann, S. Schindler, U. R. Sumaila, L. S. L. Teh, J. van Kolck, P. Visconti, and Y. Ye. 2014. A mid-term analysis of progress toward international biodiversity targets. Science 346:241-244. http://dx.doi.org/10.1126/science.1257484

Van Vliet, N., and R. Nasi. 2008. Hunting for livelihood in northeast Gabon: patterns, evolution, and sustainability. Ecology and Society 13(2): 33. [online] URL: http://www.ecologyandsociety. org/vol13/iss2/art33/

Walpole, M., R. E. A. Almond, C. Besançon, S. H. M. Butchart, D. Campbell-Lendrum, G. M. Carr, B. Collen, L. Collette, N. C. Davidson, E. Dulloo, A. M. Fazel, J. N. Galloway, M. Gill, T. Goverse, M. Hockings, D. J. Leaman, D. H. W. Morgan, C. Revenga, C. J. Rickwood, F. Schutyser, S. Simons, A. J. Stattersfield, T. D. Tyrrell, J.-C. Vié, and M. Zimsky. 2009. Tracking progress toward the 2010 biodiversity target and beyond. Science 325:1503-1504. http://dx.doi.org/10.1126/ science. 1175466

Weinbaum, K. Z., J. S. Brashares, C. D. Golden, and W. M. Getz. 2013. Searching for sustainability: are assessments of wildlife harvests behind the times? Ecology Letters 16:99-111. http://dx. doi.org/10.1111/ele.12008

Willcox, A. S., and D. M. Nambu. 2007. Wildlife hunting practices and bushmeat dynamics of the Banyangi and Mbo people of southwestern Cameroon. Biological Conservation 134:251-261. http://dx.doi.org/10.1016/j.biocon.2006.08.016
Wolf, A., C. E. Doughty, and Y. Malhi. 2013. Lateral diffusion of nutrients by mammalian herbivores in terrestrial ecosystems. PLoS ONE 8:e71352. http://dx.doi.org/10.1371/journal.pone.0071352

Worm, B., R. Hilborn, J. K. Baum, T. A. Branch, J. S. Collie, C. Costello, M. J. Fogarty, E. A. Fulton, J. A. Hutchings, S. Jennings, O. P. Jensen, H. K. Lotze, P. M. Mace, T. R. McClanahan, C. Minto, S. R. Palumbi, A. M. Parma, D. Ricard, A. A. Rosenberg, R. Watson, and D. Zeller. 2009. Rebuilding global fisheries. Science 325:578-585. http://dx.doi.org/10.1126/science.1173146

Yasouka, H. 2006. The sustainability of duiker (Cephalophus spp.) hunting for the Baka hunter-gatherers in southeastern Cameroon. African Study Monographs Supplementary Issue 33:95-120.

Zuur, A. F., E. N. Ieno, N. J. Walker, A. A. Saveliev and, G. M. Smith. 2009. Mixed effects models and extensions in ecology with R. Springer-Verlag, Berlin, Germany. http://dx.doi. org/10.1007/978-0-387-87458-6 